\title{
Laron Syndrome Research Paves the Way for New Insights in Oncological Investigation
}

\author{
Haim Werner ${ }^{1,2}, * \mathbb{D}$, Rive Sarfstein ${ }^{1}$, Karthik Nagaraj ${ }^{1}$ and Zvi Laron ${ }^{3}$ \\ 1 Department of Human Molecular Genetics and Biochemistry, Sackler School of Medicine, \\ Tel Aviv University, Tel Aviv 69978, Israel; rives@tauex.tau.ac.il (R.S.); mailkartz@gmail.com (K.N.) \\ 2 Shalom and Varda Yoran Institute for Human Genome Research, Tel Aviv University, Tel Aviv 69978, Israel \\ 3 Endocrine and Diabetes Research Unit, Schneider Children's Medical Center, Petah Tikva 49292, Israel; \\ laronz@clalit.org.il \\ * Correspondence: hwerner@tauex.tau.ac.il
}

Received: 18 October 2020; Accepted: 5 November 2020; Published: 9 November 2020

check for updates

\begin{abstract}
Laron syndrome (LS) is a rare genetic endocrinopathy that results from mutation of the growth hormone receptor $(G H-R)$ gene and is typically associated with dwarfism and obesity. LS is the best characterized entity under the spectrum of the congenital insulin-like growth factor-1 (IGF1) deficiencies. Epidemiological analyses have shown that LS patients do not develop cancer, whereas heterozygous family members have a cancer prevalence similar to the general population. To identify genes and signaling pathways differentially represented in LS that may help delineate a biochemical and molecular basis for cancer protection, we have recently conducted a genome-wide profiling of LS patients. Studies were based on our collection of Epstein-Barr virus (EBV)-immortalized lymphoblastoid cell lines derived from LS patients, relatives and healthy controls. Bioinformatic analyses identified differences in gene expression in several pathways, including apoptosis, metabolic control, cytokine biology, Jak-STAT and PI3K-AKT signaling, etc. Genes involved in the control of cell cycle, motility, growth and oncogenic transformation are, in general, down-regulated in LS. These genetic events seem to have a major impact on the biological properties of LS cells, including proliferation, apoptosis, response to oxidative stress, etc. Furthermore, genomic analyses allowed us to identify novel IGF1 downstream target genes that have not been previously linked to the IGF1 signaling pathway. In summary, by 'mining' genomic data from LS patients, we were able to generate clinically-relevant information in oncology and, potentially, related disciplines.
\end{abstract}

Keywords: growth hormone; growth hormone receptor; insulin-like growth factor-1 (IGF1); Laron syndrome; cancer protection

\section{The Growth Hormone-Insulin-Like Growth Factor 1 Endocrine Axis}

The biological actions of the growth hormone (GH)-insulin-like growth factor-1 (IGF1) axis have been clearly delineated [1,2]. The role of IGF1 as the mediator of the GH-stimulated incorporation of sulfate into cartilage was demonstrated more than sixty years ago [3]. The specific, $\mathrm{GH}$-activated serum factor, originally termed sulfation factor and then somatomedin, is now accepted as IGF1 [4]. The IGF system comprises two ligands, IGF1 and IGF2. The IGFs developed early in evolution, possibly as regulators of cellular proliferation in relation to nutrient availability $[5,6]$. At the cellular level, IGF1 functions as a progression factor required to traverse the various phases of the cell cycle [7-10]. Circulating IGF1 levels are dependent on liver production, which is tightly controlled by hypophyseal GH. In addition to its classic endocrine mode of action, a number of extrahepatic tissues display the biosynthetic machinery necessary to produce IGF1. These organs 
include the brain, kidney, stomach, and others $[1,2,6]$. The dependence of locally-produced IGF1 on $\mathrm{GH}$ stimulation is still a matter of debate.

IGF1 and IGF2 activate a common cell-surface receptor, the IGF1 receptor (IGF1R). Activation (i.e., phosphorylation) of the IGF1R tyrosine kinase domain by either IGF1 or IGF2 leads to the subsequent activation of a cytoplasmic enzymatic cascade that is directly responsible for the execution of the metabolic and growth actions of hormones [11,12]. The IGF1R is regarded as one of the most potent anti-apoptotic, pro-survival growth factor receptors [13-16]. The IGF2 receptor (IGF2R) is identical to the mannose 6-phosphate receptor, a cell-surface protein that binds IGF2 with high affinity and targets it for lysosomal degradation $[17,18]$. IGF2R lacks a tyrosine kinase domain and, therefore, is not involved in cell signaling. The activities of IGF1/IGF2 are modulated by a family of at least six IGF-binding proteins (IGFBPs) that carry the IGFs in the circulation and extracellular space $[19,20]$.

The present review is aimed at dissecting the role of the GH-IGF1 axis in cancer biology. Our comprehensive analyses of Laron syndrome (LS) patients, a rare endocrinopathy associated with major growth deficits, generated novel insights that, we believe, might have translational relevance in oncology. As described below, gain-of-knowledge was made possible due to a number of recent technological and scientific breakthroughs, including the availability of genomic and proteomic platforms designed for the global exploration of massive amounts of data. The analyses presented here are ultimately aimed at delineating a molecular signature associated with cancer protection.

\section{The GH-IGF1 Axis and Growth Retardation}

Growth retardation in infants is multifactorial, although a large portion of cases remain idiopathic because no specific (genetic or other) defect can be identified [21]. Prenatal IGF1 gene expression is GH-independent and becomes GH-dependent shortly before birth [2]. IGF1 expression remains dependent on GH secretion during postnatal life. Congenital IGF1 deficiencies are characterized by low serum IGF1 but normal to elevated GH production [22]. These conditions result from: (i) a GH releasing hormone-receptor (GHRH-R) defect; (ii) GH gene deletion (isolated GH deficiency, IGHD); (iii) GH receptor (GHR) gene deletion or mutation (Laron syndrome); (iv) IGF1 gene deletion or IGF1R gene defect. Additional conditions leading to congenital IGF1 deficiency are defects of post-GHR signaling (e.g., STAT5 defects) as well as a number of disorders associated with reduced IGF1 stability or availability, including acid-labile subunit (ALS) mutation and molecular defect of the metalloproteinase pregnancy-associated plasma protein A2 (PAPP-A2) [23-30].

The essential role played by the IGF system in growth and development is illustrated by the severe growth deficits observed in mice, in which various components of the IGF system, including ligands and receptors, were disrupted by homologous recombination [31,32]. Heterozygous mice for a disrupted igf1 allele had a body weight at birth that was $~ 10-20 \%$ lower than that of wild-type animals. Homozygous igf1 null mice weighed $\sim 40 \%$ less than wild-type animals and exhibited a very high perinatal mortality rate as well as a number of phenotypic alterations. Genetic inactivation of the igflr gene yields the most severe phenotype in this pathway, including neural, muscular, bone, and skin defects. Homozygous igfir null mice die at birth as a result of respiratory failure caused by acute muscular hypoplasia [33].

To distinguish between the endocrine and autocrine/paracrine effects of IGF1 on growth and development, Yakar et al. generated mice with liver-specific deletion of the igf1 gene [34]. Despite a major $(\sim 80 \%)$ reduction in circulating IGF1 levels, the overall growth of these animals was not different from that of their control littermates. These findings demonstrate that despite its minor contribution to the total IGF1 concentration in blood, locally-produced (extrahepatic) IGF1 has a critical role in growth and development. On the other hand, List et al. reported that liver-specific disruption of the GHR gene led to a major reduction in serum IGF1 levels and a stunted growth phenotype, especially later in life [35]. This phenotype was associated with increased local IGF1 production, altered body composition, 
and abnormal adipokine profiles. The differences between both animal models reflect the complexity of this hormonal system and the distinct impact of specific gene defects.

\section{IGF1: A Validated Cancer Risk Factor}

A high cellular turnover in epithelial tissues is generally regarded as a contributing factor to the propagation of a neoplasm [4]. The proliferative and antiapoptotic activities of IGF1 led to several observational studies that were aimed at elucidating the potential connection between circulating IGF1 levels and increased risk of cancer. Large epidemiological studies have suggested that high endocrine IGF1 levels are associated with an augmented risk for breast, prostate, lung, sarcoma, and colorectal cancer [36]. Specifically, in a prospective nested control study (the Nurse's Health Study), the relative risk (RR) of breast cancer in premenopausal women was 4.6 in the upper tertile of IGF1 values in comparison to women in the lower tertile [37]. The RR increased to 7.3 when the concentrations of IGFBP3 (a protective factor) were included in the analysis. Likewise, results of the Physicians' Health Study revealed that the RR to develop prostate cancer was 4.3 among men in the upper quartile of IGF1 values compared to individuals in the lower quartile [38]. It is noteworthy that IGF1 levels were measured an average of seven years before the diagnosis of prostate cancer. In addition to hormone-dependent prostate and breast carcinomas, the role of IGF1 as a risk factor was evaluated in various non-hormone-dependent malignancies. Analyses of colon cancer risk in the Nurse's Health Study and the Physician's Health Study showed an increased risk in individuals with the highest IGF1 values [39].

Several mechanisms have been suggested to explain the role of the IGF system in the initiation and/or progression of neoplasia [40]. Although IGF1 was shown to increase chromosomal fragility under experimental conditions [41], it is usually considered to be non-genotoxic. Whether the use of high doses of IGF1 induce DNA damage or mutations in humans has not been investigated. However, the proliferative actions of IGF1 have been well characterized. A biologically-based, computerized description of carcinogenesis suggested that an increase in cell proliferation could account for the carcinogenicity of non-genotoxic compounds [42]. Once a malignant transformation event has occurred, cell survival of already transformed cells depends on IGF1 action. The disruption of internal checks associated with the neoplastic phenotype is further emphasized by the finding that IGF1 action can override the cellular signals of apoptosis [7].

\section{Laron Syndrome: A Prototypical Case of Congenital IGF1 Deficiency}

Laron syndrome, or primary GH insensitivity (OMIM\#262500), is an autosomal recessive hereditary disease caused by molecular defect of the GHR gene, leading to GH resistance and dwarfism. LS constitutes the best-characterized entity under the umbrella of congenital IGF1 deficiencies. Historical aspects related to the discovery of the disease as well as the impact of this syndrome on our current understanding of GH-IGF1 pathophysiology have been reported elsewhere [43-46]. The disease was originally identified in the late 1950s in Jewish patients of Yemenite origin [45]. Following the first report in 1966, LS patients of various ethnic origins were identified in various regions of the world [47]. Of interest, most of the patients were of Mediterranean, Middle Eastern, or South Asian origin, including a large cohort in Ecuador [48]. According to most estimates, the approximate number of diagnosed LS patients worldwide ranges between 400 and 500 individuals.

Whereas the clinical history, appearance, and laboratory findings of the first LS patients resembled those described earlier in children with IGHD, a recently developed radioimmunoassay [49] revealed that their serum GH levels were very high, in the so-called acromegalic range [47]. Initial immunological studies established that the structure as well as the immunogenic properties of the circulating GH molecule were normal, as proven by radio-receptor assays using human liver membranes [50]. However, liver biopsies from two LS patients showed no specific binding of ${ }^{125} \mathrm{I}$-hGH to liver microsomes [51]. These laboratory findings provided the first evidence that LS patients have a defective GHR that causes GH insensitivity and diminished liver IGF1 production. As a result of the reduced 
endocrine IGF1 levels, there is a relaxation of the inhibitory feed-back regulatory loop of GH biosynthesis at the hypophyseal level, with ensuing augmentation of circulating GH levels (Figure 1).

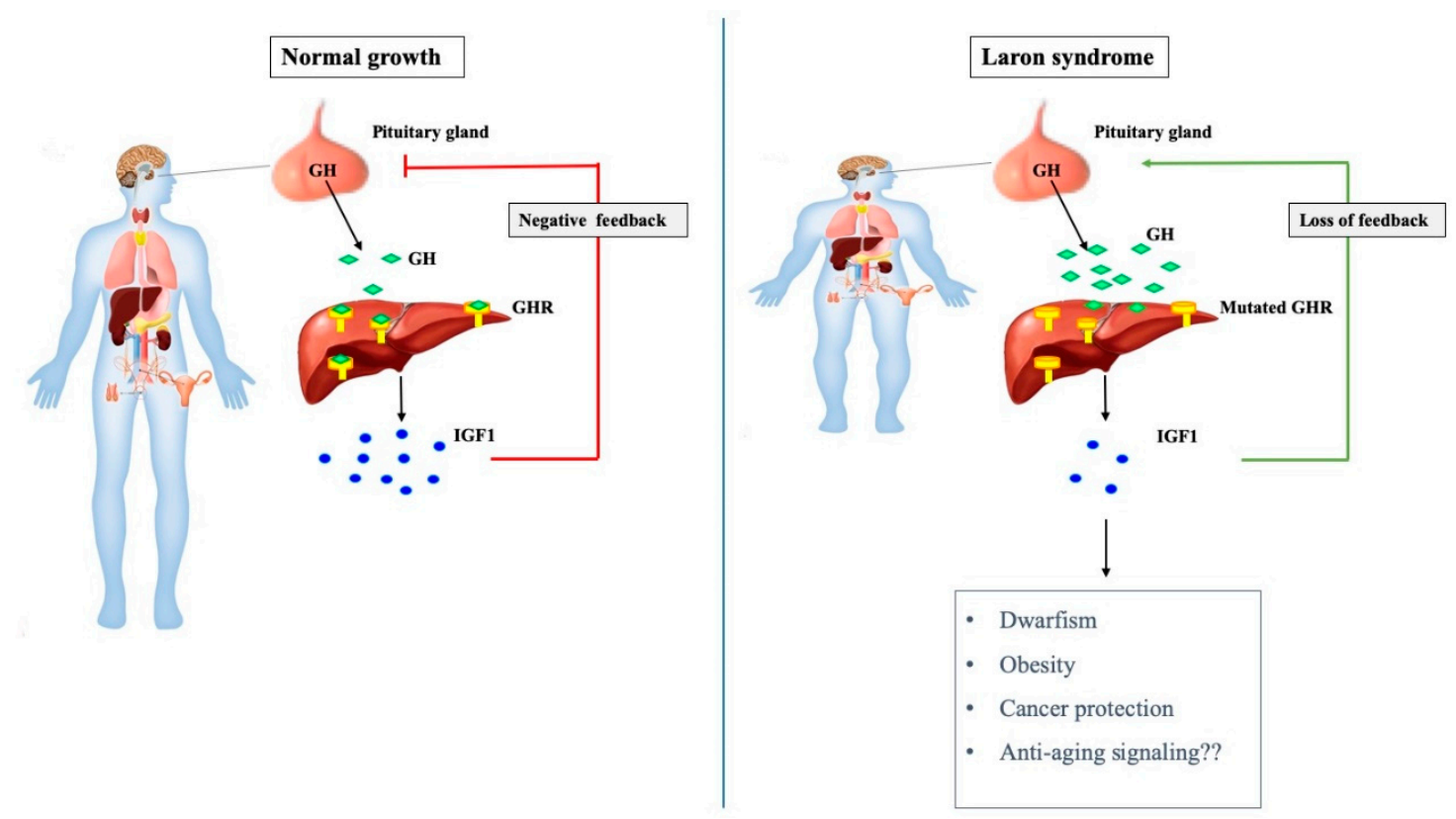

Figure 1. The growth hormone-IGF1 axis in normal and pathological growth. Pituitary-produced growth hormone (GH) stimulates insulin-like growth factor-1 (IGF1) secretion from the liver, leading to bone elongation and longitudinal growth (left panel). Laron syndrome (LS) is associated with mutation of the GHR gene, as a result of which the liver (and, most probably, additional extrahepatic tissue) is no longer able to produce IGF1 at physiological levels in response to GH stimulation (right panel). Abrogation of IGF1 biosynthesis leads to impaired growth and concomitant relaxation of negative feed-back regulation of GH production at the pituitary gland. Loss of inhibitory control results in very high circulating GH levels. In addition to short stature, LS is associated with obesity and protection from cancer. Enhanced longevity has been demonstrated in animal models of LS ('Laron' mouse).

The identification of an exon deletion or mutation of the GHR gene as the molecular defect underlying the etiology of LS was reported in 1989 [52,53]. Sixteen different molecular defects were found in the Israeli cohort, whereas the total number known today amounts to over 70 [54,55]. The majority of LS patients from the Ecuadorian cohort are homozygous for an A to G splice site mutation at position 180 in exon 6 of the GHR gene [55]. As the same mutation was found in a Jewish girl of Moroccan origin, it is assumed that the gene was brought to South and Central America by Sephardic Jews fleeing the Spanish Inquisition in the 15-16th centuries [56]. Despite variability in the mutational spectrum, the phenotypic consequences are remarkably similar, i.e., dwarfism and lack of GH signaling. The typical features of classical LS are short stature ( -4 to -10 SDS below median height), typical face, obesity, high serum GH, and low to undetectable serum IGF1, unresponsive to the administration of exogenous GH [45]. An animal model of LS (the 'Laron' mouse) was engineered by disrupting the GH-binding protein gene [57]. Similar to humans, Laron mice have low IGF1 and high inactive GH levels.

The only effective treatment for LS patients is biosynthetic IGF1, available since 1986, which leads to acceleration of linear growth [58,59]. According to most clinical reports, the growth velocity during the first year of treatment is higher than in subsequent years. However, despite the effective stimulation of linear growth, the growth velocity is not as intense as that achieved with hGH in GH deficient patients [60]. With continuous treatment, there is also progressive growth of the extremities and a fast catch-up growth of the head circumference. 


\section{Laron Syndrome and Cancer Protection: Epidemiological Data}

As alluded to above, individuals with high circulating IGF1 levels, as well as those with insulin resistance and/or obesity, are at increased risk for several types of cancer. Nevertheless, it is not clear whether IGF1 plays, by endocrine, paracrine, or autocrine mechanisms, a role in the etiology or only in the progression of neoplasms [61]. To provide a different perspective on the linkage between GH-IGF1 and cancer, prevalence of malignancies was recently assessed in a group of patients with congenital IGF1 deficiency [62,63]. The cohort investigated included 538 patients, divided into the following diagnostic groups: (i) LS $(n=230)$; (ii) IGHD $(n=116)$; (iii) GHRH-R mutations $(n=79)$; (iv) congenital multiple pituitary hormone deficiency (cMPHD) $(n=113)$. In addition, the analyses included 752 first-degree family members (out of which 274 were siblings) and 131 further relatives.

The analyses revealed that none of the 230 LS patients (up to the age of 85) had developed a malignancy, despite the fact that 66 of them had been treated with IGF1 and two had received hGH as well. Eighteen $(8.3 \%)$ instances of malignancy were reported among 218 first-degree relatives, twenty-five (22.1\%) cases were reported in 113 further relatives, and five (5.8\%) tumors were reported in 86 siblings of LS patients. The differences between the prevalence of malignancies in LS versus first-degree relatives, further relatives, or siblings were regarded as statistically significant (Table 1).

Table 1. Epidemiological analyses of cancer prevalence in Laron syndrome patients. Prevalence of malignancies in LS and relatives was assessed by replying to a questionnaire that was filled-in by the primary care physician (Adapted from [63]).

\begin{tabular}{lllll}
\hline & Laron Syndrome & First-Degree Relatives & Further Relatives & Sibilings Only \\
\hline Total number (n) & 230 & 218 & 113 & 86 \\
\hline $\begin{array}{l}\text { Malignancies } \\
\text { (number of events) }\end{array}$ & 0 & 18 & 25 & 5 \\
\hline $\begin{array}{l}\text { Prevalence of } \\
\text { malignancy (\%) }\end{array}$ & 0 & 8.3 & 22.1 & 5.8 \\
\hline$p$-value (versus LS) & $<0.001$ & $<0.001$ & 0.005 \\
\hline
\end{tabular}

Differences in cancer incidence between patients and relatives were also noticed in the other diagnostic groups. Specifically, out of the 116 patients with IGHD, only one boy $(0.9 \%)$ who suffered from xeroderma pigmentosum was reported to have a basal cell carcinoma. Fifty-nine of the IGHD patients had been treated with hGH, including the boy who developed the carcinoma. In comparison, $3.4 \%, 30.8 \%$, and $2.1 \%$ cases of cancer were reported in first-degree relatives, further relatives, and siblings, respectively, of IGHD patients. Out of the 79 patients with GHRH-R mutations (out of which twelve were previously treated with $\mathrm{hGH}$ ), three (3.8\%) had cancer (one of them treated with $\mathrm{hGH}$ ) and so had three (2.7\%) out of 113 patients with cMPHD. Epidemiological data are consistent with the concept that congenital IGF1 deficiency, or deficiency in early childhood, confers protection against future development of cancer. As mentioned above, this inference reaches statistical significance in LS patients. Similar trends (although not always reaching significance) were seen in the other pathologic entities. Reports of protection from cancer were also reported by Guevara-Aguirre and colleagues in the Ecuadorian cohort of LS patients [64]. In this population, tumors were not a main cause of death among patients who died before 1988. Moreover, there was no proof of cancer among 99 LS patients since 1988. Cancer frequency among relatives was similar to the Ecuadorian population ( 20\%). Of interest is that a double heterozygous LS patient developed an ovarian carcinoma (personal communication)

An additional aspect that deserves consideration is the fact that tumor spread might reflect immune escape of circulating malignant cells. Of notice, congenital IGF1 deficiencies were reported not to be associated with immune deficiency [45]. Data described in the following sections are consistent with the notion that cancer protection in LS is most probably not related to improved immune surveillance but rather to a reduction in the primary events leading to cancer development. Finally, epidemiological 
data are supported by animal experiments using the GH-R/GH-BP knockout ('Laron') mouse [65]. Specifically, crossing of the C3(1)T antigen mouse with the GH-R/GH-BP knockout resulted in markedly reduced prostate cancer development [66].

\section{Genome-Wide Profiling of Laron Syndrome Patients}

The association between life-long diminished IGF1 levels in congenital deficiencies and cancer protection highlights the central role of IGF1 in the etiology of malignancies. Recognition of this linkage prompted us to conduct a genomic profiling of LS patients aimed at identifying IGF1-dependent genes and signaling pathways that are differentially expressed in LS and that may shed information on the molecular foundation for cancer evasion in this condition. Studies were based on the collection of Epstein-Barr virus (EBV)-immortalized lymphoblastoid cell lines derived from LS patients, relatives, and healthy controls [67]. The collection is available at the Laboratory for the Genetics of Israeli Populations (Tel Aviv University, Israel).

EBV-immortalized lymphoblastoid cell lines constitute an important tool in biomedical research [68]. Cell lines were generated from lymphocytes isolated from blood samples. Despite viral immortalization, the cells are regarded as non-carcinogenic. Furthermore, cells retain the genomic characteristics of the donors and are, therefore, perfectly suited for this type of analysis. Of importance, given that the cells are usually grown in a serum-containing medium, caution has to be exerted when extrapolating experimental data generated with these cells to the in vivo conditions. Moreover, comparisons with cancer-derived cells are not always feasible. In spite of these limitations, the use of EBV-immortalized lymphoblastoids had an enormous impact on genomic research.

RNA obtained from four female LS patients and four controls of the same age range $(\mathrm{LS}, 44.25 \pm 6.08 \mathrm{yr}$; controls, $51.75 \pm 11.3 \mathrm{y}$; mean $\pm \mathrm{SD} ; p$-value $=0.29)$ and ethnic origin (Yemen, Irak, Iran) was used for genomic analyses. Affymetrix GeneChip ${ }^{\circledR}$ Human Gene 1.0 ST Arrays, which offer whole-transcript coverage, were used. These arrays interrogate 28,869 well-annotated genes and non-coding RNAs and have greater than $99 \%$ coverage of sequences present in the RefSeq database.

Hierarchical cluster analysis using the Partek Genomics Suite software led to the identification of thirty-nine annotated genes that were differentially expressed in LS (either up- or down-regulated) compared to controls (with a $p$-value of $<0.05$ and fold-change difference cutoff $>|2|$ ) (Figure 2A). Principal component analysis (PCA) revealed a good discrimination between experimental groups. The bioinformatic analyses described below highlight the power of post-genomic platforms to study previously unrecognized aspects of IGF1 biology.

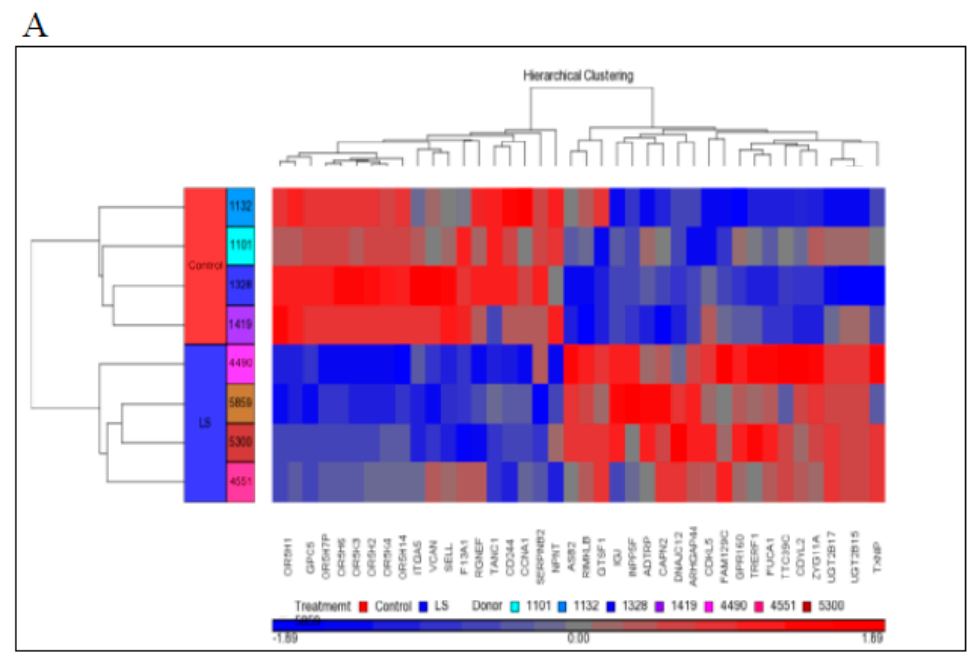

Figure 2. Cont. 
B

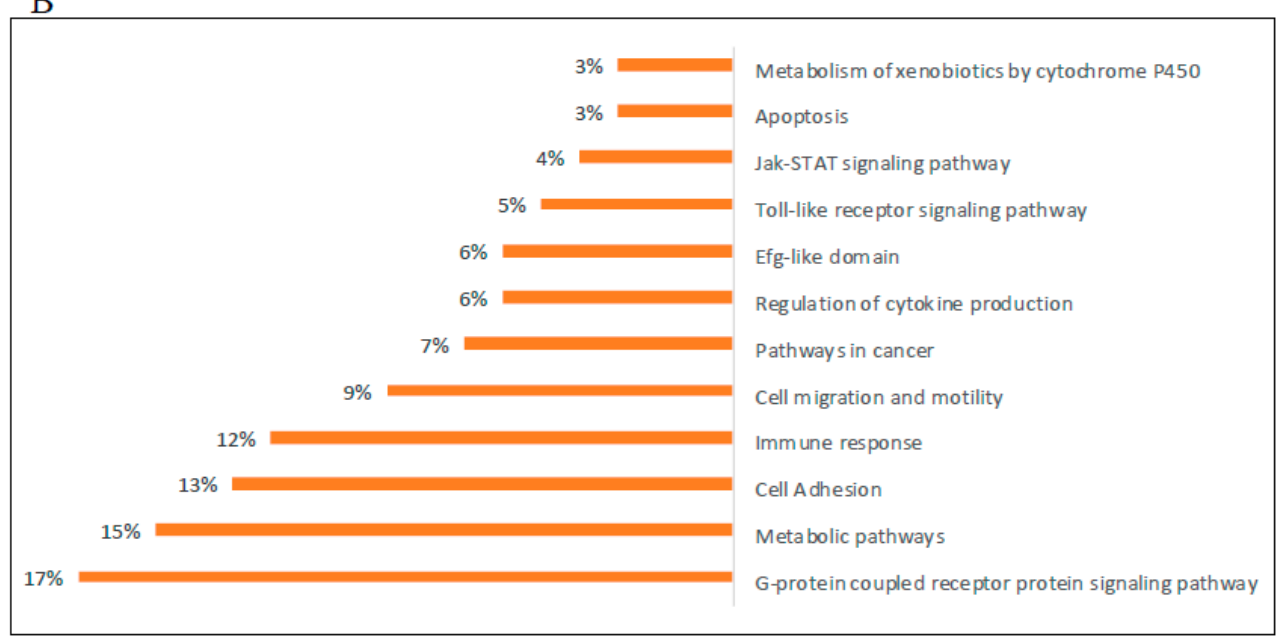

Figure 2. Genomic analysis of Laron Syndrome patients. (A) Hierarchical cluster analysis of differentially expressed genes in lymphoblastoids derived from four female LS patients and four controls of the same age range (LS, $44.25 \pm 6.08 \mathrm{yr}$; controls, $51.75 \pm 11.3 \mathrm{y}$ ) and ethnic (Yemen, Irak, Iran) origin. The figure depicts a cluster of 39 differentially expressed genes (FC $>2$ or $<$ than -2 and $p$-value $<0.05$ ). Up-regulated genes are shown in red and down-regulated genes are shown in blue. FC, fold change. This panel was obtained from [67]. (B) Functional analysis of differentially represented signaling pathways in LS. Bioinformatic analyses were conducted using the David and WebGestalt platforms. The $\%$ values in each category correspond to the percentage of the total number of differentially expressed genes.

\section{Bioinformatic Analyses Identify New IGF1 Target Genes and Signaling Pathways}

Comprehensive functional enrichment analyses were performed using the David (david.ncifcrf.gov) and WebGestalt (www.webgestalt.org) platforms. The aim of these studies was to find co-expressed genes sharing the same pathways. Our analyses identified a number of genes that are differentially expressed in lymphoblastoid cells of LS patients compared to healthy controls of the same gender, age, and ethnic group. This differential expression may, potentially, explain the evasion of LS patients from cancer. Bioinformatic analyses revealed that differences in gene expression occur in several pathways, including apoptosis, metabolic control, cytokine-cytokine receptor interaction, Jak-STAT and PI3K-AKT signaling, etc. A schematic diagram of differentially represented pathways in LS is presented in Figure 2B.

Analyses revealed that genes involved in the control of cell cycle, motility, growth, and oncogenic transformation were, for the most part, down-regulated in LS-derived, compared to control, cell lines. These genes include, among others, cyclin A1, cyclin D1, serpin B2, versican, and transcription factor Sp1 (Table 2). Sp1 has been identified as a key regulator of IGF1R gene transcription $[15,16]$ and it is typically overexpressed in malignantly-transformed cells. Hence, bioinformatic data are consistent with the notion that life-long lack of exposure to endocrine (and, probably, locally-produced) IGF1 in LS might lead to down-regulation of genes, with a positive impact on survival and proliferation. This scenario is consistent with the view that IGF1 exposure activates epigenetic and transcription pathways that are critical for mitogenic gene expression. Diminished IGF1 levels in LS patients lead to relaxation of expression and/or activation of pro-survival, anti-apoptotic signaling pathways, with important consequences in terms of cancer avoidance. 
Table 2. Differentially-regulated genes in Laron syndrome. Bioinformatic analyses identified sets of over- and under-represed genes in LS-derived lymphoblastoid cells that might underlie cancer protection in this condition.

\begin{tabular}{cc}
\hline Genes up-Regulated in LS & Biological Role \\
\hline UDP glucuronosyltransferase 2 family & Elimination of xenobiotic substances \\
\hline G-protein coupled receptor & Signaling \\
\hline Thioredoxin interacting protein & Metabolic regulation \\
\hline ZYG11A & Cell cycle regulator \\
\hline CAPN2 & Extracellular matrix disassembly \\
\hline Genes down-regulated in LS & Biological role \\
\hline Cyclin A1 & Cell cycle \\
\hline AKT3 & Apoptosis \\
\hline Versican & Extracellular matrix proteoglycan \\
\hline Olfactory receptor & Detection of odor molecules \\
\hline Nephronectin & Cell adhesion \\
\hline Serpin B2 & Apoptosis and proliferation \\
\hline Sp1 & Transcription factor \\
\hline
\end{tabular}

Conversely, genomic analyses revealed enhanced expression of genes associated with protection from toxic xenobiotic substances and metabolites in LS-derived lymphoblastoid cells. Specifically, the UDP-glycosyltransferase (UGT) genes [69,70], which code for enzymes that convert xenobiotic and endobiotic substances into lipophilic compounds, thereby facilitating clearance from the body as part of a liver detoxification system, were several-fold higher in LS, compared to control, cells. Of special interest is the elevated expression of both UGT2B15 and UGT2B17 (11- and 7-fold, respectively) in LS. The UGT enzymes encoded by both genes facilitate the catabolism of steroid hormones involved in the etiology of certain cancers, in particular breast and prostate tumors. Thus, data point towards an enhanced capacity of LS cells to respond to a variety of exogenous cellular insults (e.g., xenobiotic substances) as well as endogenous metabolites (e.g., steroid hormones). The ability of LS cells to act in response to oxidative stress is described below.

Finally, genomic analysis identified ZYG11A, a member of the ZYG11 gene family of cell cycle regulators, as a highly expressed (fold-change $=3.0$ versus controls) gene in LS cells. Consistently, ZYG11A was inhibited by IGF1 in endometrial cancer cells in a p53-dependent manner [71]. In addition, bioinformatic analyses identified nephronectin, an intracellular and secreted extracellular matrix protein with important roles in kidney development, as the top down-regulated gene in LS cells (fold-change $=-3.12$ versus controls) [72]. Neither ZYG11A nor nephronectin have been previously linked to the IGF1-signaling pathway. The biological and clinical implications of these novel regulatory links merit further investigation. In particular, it will be of interest to elucidate the mechanistic events responsible for the linkage between ZYG11A and/or nephronectin dysregulated expression and cancer protection.

\section{LS Cells Display Altered Mitogenic Properties}

Following identification of genes and signaling pathways that are differentially represented in LS, it was of importance to establish the impact of these paths on the biological properties of LS cells. Above all, it was of critical relevance to address the mechanisms that might underlie cancer protection in this condition. The following questions were formulated:

(i) What are the mitogenic properties of LS-derived cells?

(ii) Are the different phases of the cell cycle altered in LS?

(iii) What is the apoptotic index of LS cells? 
(iv) Do LS cells respond differently to oxidative stress?

(v) Is autophagic machinery involved in cancer evasion in LS?

XTT colorimetric assays revealed that the proliferation rate of LS-derived lymphoblastoid cells was reduced by 50\% (Figure 3A) [67]. Cell cycle analyses showed that the proportion of cells in the G2-M phase in response to etoposide (a DNA-damaging agent) in LS was reduced by $50 \%$ in comparison to controls (2.2\% in LS compared to $4.4 \%$ in control cells). Similarly, the proportion of LS cells in S phase was reduced in comparison to healthy cells. Combined, the data indicate that the response of LS cells to DNA damage in terms of cell cycle progression was attenuated (Figure 3B). Along the same lines, flow cytometry indicate that the percentage of apoptotic cells under basal conditions was $40 \%$ higher in LS compared to controls (Figure 3C). Likewise, the percentage of necrotic cells was increased by $27 \%$ in LS.
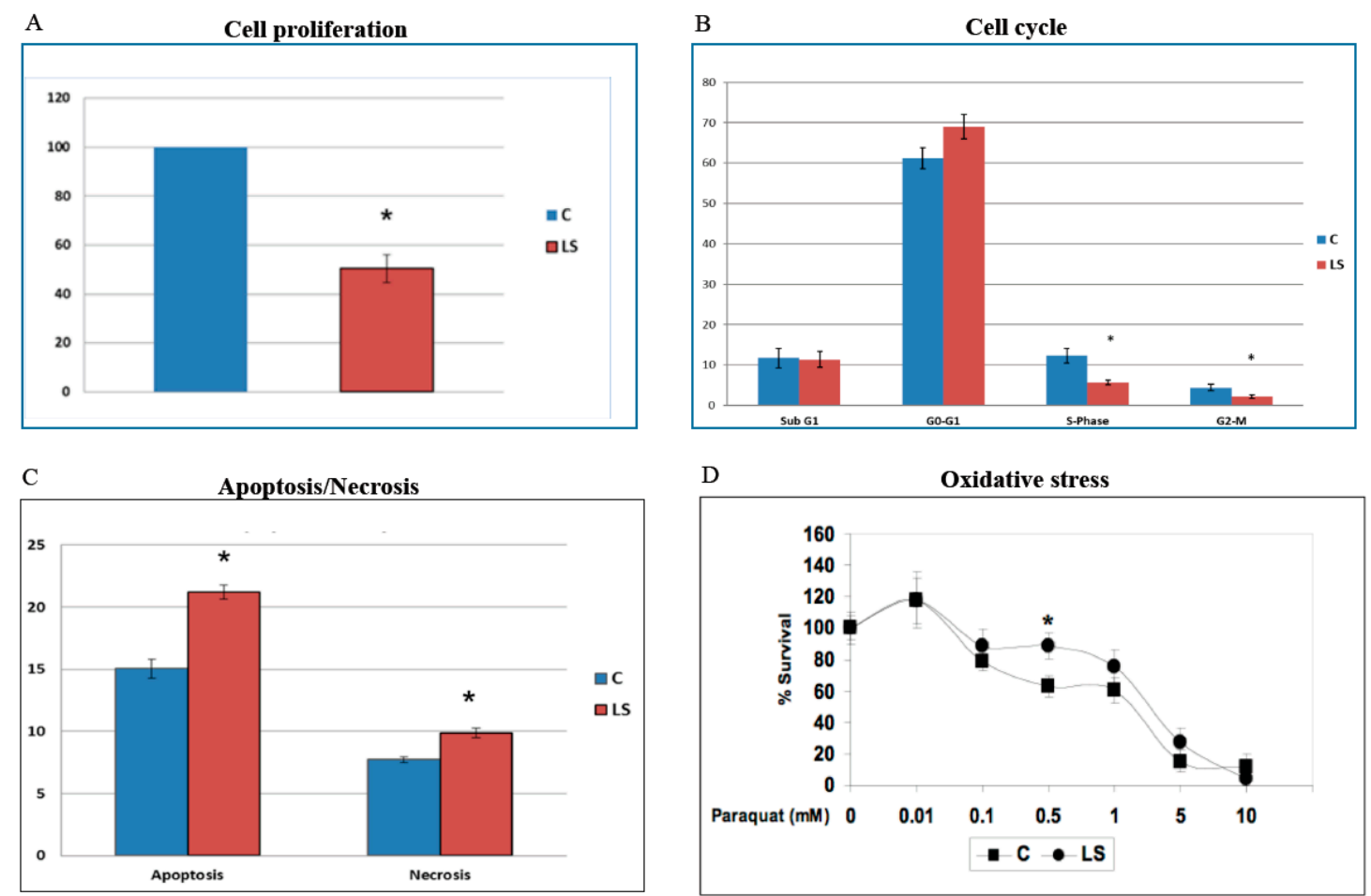

Figure 3. Analysis of biological functions in LS cells. (A) Cell proliferation. LS- and control-derived lymphoblastoid cells were maintained in a serum-free, IGF1-free medium for three days, after which proliferation was assessed using an XTT colorimetric kit. The statistical significance of differences between groups was assessed by a Student's $t$-test. *, significantly different versus control $(p<0.05)$. (B) Cell cycle. Lymphoblastoids were exposed to etoposide (a DNA-damaging agent) for $24 \mathrm{~h}$, after which cells were stained with propidium iodide and analyzed with a FACScalibur system to determine the percentage of cells in G0-G1, S, and G2-M phases. The graph presents the percentage of cells within each cell cycle phase. (C) Apoptosis/Necrosis. Basal apoptosis and necrosis were measured by flow cytometry analysis after staining cells with an Annexin- $V$ antibody and propidium iodide. Necrotic cells were stained with propidium iodide and Annexin V, whereas apoptotic cells were stained only with Annexin V. (D) Oxidative stress. Cells were grown to confluence, after which the medium was changed to a fresh full medium in the presence of increasing doses of paraquat dichloride. Paraquat generates superoxide anion, which leads to the formation of toxic reactive oxygen species, such as hydrogen peroxide and hydroxyl radical, and the oxidation of cellular NADPH. Proliferation in response to oxidative damage was measured using an XTT kit. The graph depicts a pair of LS-derived and control cells, normalized for age and ethnic origin. A value of $100 \%$ was given to the cell number at time zero. Data described here were originally reported in [67]. 
To examine the hypothesis that cancer protection in LS might be associated with enhanced resistance to oxidative damage, lymphoblastoids were treated with increasing doses of the oxidative agent paraquat for different time periods, after which cell survival was assessed. Results of XTT assays indicate that LS-derived lymphoblastoids display enhanced survivability in comparison to control cells over a broad range of paraquat concentrations $(0.01-10 \mathrm{mM})$ (Figure 3D).

Autophagy is a major housekeeping mechanism, critically involved in the maintenance of normal cellular homeostasis [73]. This mechanism enables the clearance of damaged proteins and organelles via formation of special vesicles termed autophagosomes. The role of autophagy, however, extends beyond the removal of impaired cell components to many physiological and pathological processes, including oxidative stress and tumorigenesis. Proteins LC3 $\beta$ and P62 are involved in different aspects of autophagosome biology and are regarded as valid autophagy markers $[74,75]$. Western blots revealed that basal LC $3 \beta$ levels were reduced, whereas P62 values were elevated, in LS cells [67]. In addition, we discovered a major paraquat-induced increase in P62 levels in patient's cells, suggesting the existence of a differentially-regulated autophagy machinery in LS. We assume that these autophagic adaptations correlate with enhanced survival of LS cells in response to oxidative stress.

\section{Identification of Thioredoxin-Interacting Protein as a New Target for IGF1 Action}

Among other genes shown to be differentially represented in LS, the finding that thioredoxin-interacting protein (TXNIP) mRNA levels were more than two-fold higher in LS than in healthy control-derived lymphoblastoid cell lines is of special interest and identifies new, previously unrecognized connections between IGF1 and the mitochondrial machinery (Figure 4A). TXNIP belongs to the $\alpha$-arrestin family [76] and was initially discovered as a vitamin D3-induced gene in leukemia [77]. TXNIP binds to the catalytic active center of reduced thioredoxin (TRX) and inhibits its expression and activity, highlighting the critical participation of TXNIP in redox regulation [78-80].

Consistent with its enhanced expression in a depleted IGF1 milieu (such as the one typical of LS), addition of exogenous IGF1 (as well as insulin, albeit with lower potency) reduced TXNIP levels in different cultured cells (Figure 4B). The effect of IGF1 on TXNIP gene expression was mediated at the level of transcription, as revealed by TXNIP promoter transfection assays [81]. Both oxidative and glucose stresses led to marked increases in TXNIP levels, which were abrogated by IGF1 treatment (Figure 4C). Finally, oxidative insult resulted in enhanced TXNIP expression in LS, but not control, lymphoblastoid cells (Figure 4D).

Given the fact that IGF1 is a major regulator of cell survival and in view of the finding that IGF1 inhibits the oxidative stress-induced TXNIP upregulation, we envision a scenario in which IGF1 could inhibit apoptosis by down-regulating TXNIP at the transcriptional level (Figure 4E). The finding that TXNIP levels are increased in response to oxidation in patient-derived, but not control, lymphoblastoid cells is of major translational relevance. Independent of redox regulation, TXNIP also functions as a regulator of glucose metabolism [82]. Finally, the recent report that TXNIP levels are increased in diabetes is consistent with the enhanced susceptibility of LS patients to develop type 2 diabetes mellitus [83].
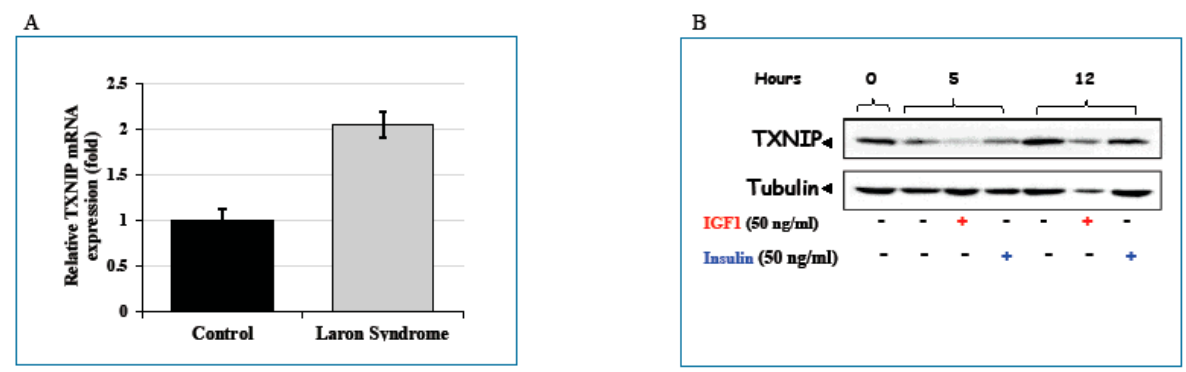

Figure 4. Cont. 

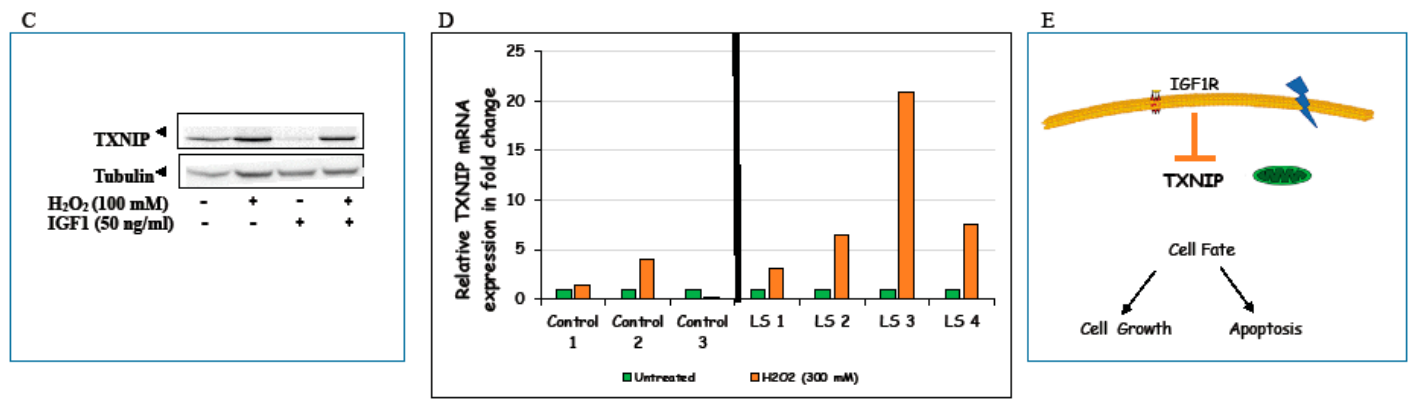

Figure 4. Regulation of thioredoxin-interacting protein (TXNIP) expression and action by IGF1. (A) Expression of TXNIP in LS cells. Total RNA was extracted from LS-derived and control lymphoblastoid cells and TXNIP mRNA levels were measured by RT-QPCR. (B) Effect of IGF1/insulin on TXNIP levels. HEK293 cells were starved for $24 \mathrm{~h}$, after which they were treated with IGF1 or insulin $(50 \mathrm{ng} / \mathrm{mL})$ for 5 or $12 \mathrm{~h}$. TXNIP levels were then measured by Western blots. (C) Effect of oxidative stress on TXNIP levels. Serum-starved HEK293 cells were treated with $\mathrm{H}_{2} \mathrm{O}_{2}(100 \mathrm{mM})$ or IGF1 or both for $2 \mathrm{~h}$, after which TXNIP levels were measured by Western blots. (D) Effect of oxidative stress on TXNIP levels in LS-derived and control lymphoblastoid cell lines. Four individual LS-derived and three control lymphoblastoid cell lines were treated with $300 \mathrm{mM}$ of $\mathrm{H}_{2} \mathrm{O}_{2}$ or left unstimulated. Cells were harvested after $2 \mathrm{~h}$ and levels of TXNIP mRNA were measured by RT-QPCR. A value of 1 was given to TXNIP mRNA levels in untreated cells (green bars). (E) Schematic representation of the regulation of TXNIP expression by IGF1. TXNIP is a metabolic gene that functions as an oxidative and glucose sensor. TXNIP mRNA levels were more than two-fold higher in LS-derived lymphoblastoid cells than in healthy control cells. IGF1 was shown to exert its anti-apoptotic effect via downregulation of TXNIP expression. Part of the data shown here was originally reported in [81].

\section{Deregulated Expression of IGFBPs in LS Contributes to Cancer Protection}

Given the important role of IGFBPs in modulation of IGF1/IGF2 action [19], we investigated the impact of congenital IGF1 deficiency on IGFBPs expression [84]. QRT-PCR analyses revealed that IGFBP-2, -5 , and -6 mRNA levels were reduced in LS-derived lymphoblastoids compared to those from healthy controls (Figure 5). Differences in mRNA levels were consistent with those at the protein level, as demonstrated by Western blots and confocal immunofluorescence. IGFBP-2 is most consistently described as pro-tumorigenic and it is reported to increase T-cell proliferation [85]. The decrease in IGFBP-2 levels in LS cells is, therefore, consistent with a protective action against cancer. IGFBP-5 has also been shown to promote T-cell migration [86] and IGFBP-6 has recently been shown to be a chemotactic agent [87]. The involvement of these specific IGFBPs in cancer protection and, in particular, their potential effects on tumor immunity merit further investigation.

On the other hand, basal IGFBP-3 levels were higher in LS than in control lymphoblastoid cultures. In view of the fact that IGFBP-3 generally functions as an anti-proliferative binding protein, increased IGFBP-3 levels may contribute to cancer protection in LS [88]. Studies have shown that adult and pediatric subjects with LS have decreased circulating IGFBP-3 levels [89,90]. This decrease is expected since IGF1 is a major positive regulator of IGFBP-3 stability. Thus, administration of IGF1 to LS patients led to increased plasma IGFBP-3 levels [91,92]. The discrepancy between in vitro and in vivo studies probably stems from the fact that lymphoblastoids were maintained in serum(and IGF1-) containing medium. As mentioned in Section 6, EBV-immortalized lymphoblastoid cell lines do not always replicate the in vivo situation and caution must be exerted when analyzing the data generated with this experimental system. 


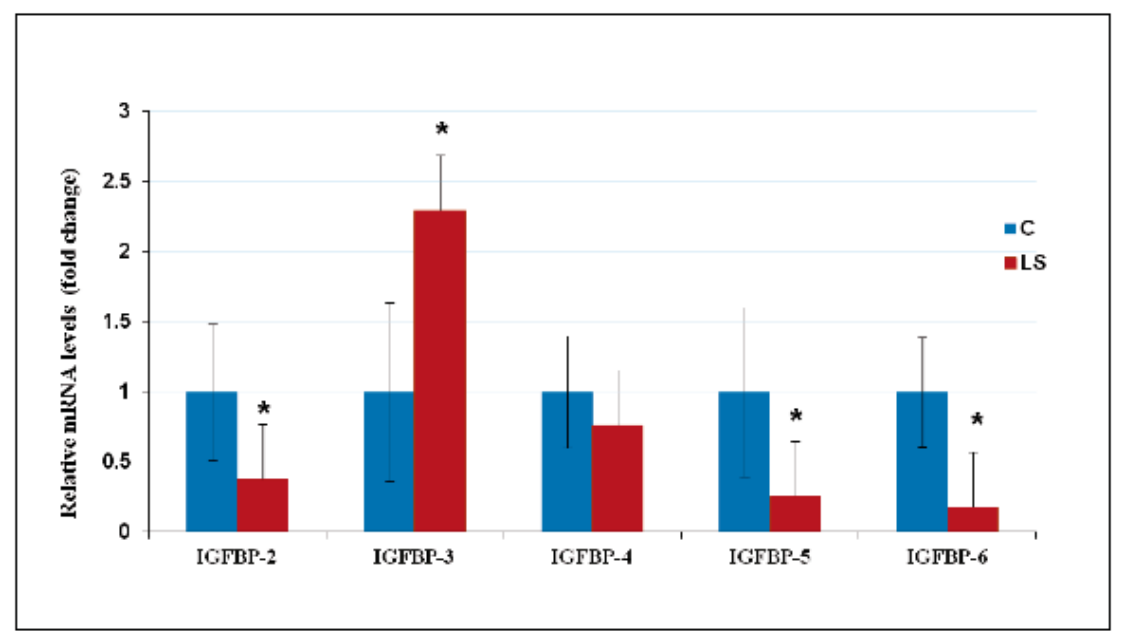

Figure 5. QRT-PCR analysis of IGF-binding protein (IGFBP) mRNA levels in LS cells. Lymphoblastoid cell lines derived from four LS patients (red bars) and four controls (blue bars) of the same age range, gender, and ethnic origin were harvested, after which total RNA was prepared and IGFBPs' mRNA levels were measured by QRT-PCR. Primers employed are described in [84]. For each IGFBP mRNA, a value of 1 was given to the level exhibited by control cells. Bars denote mean $\pm \mathrm{SD}(n=4) .{ }^{*}, p<0.05$ versus respective control. Data shown here were originally reported in [84].

Finally, experiments were conducted to assess IGFBPs' responses to oxidative stress [84]. Data indicate that IGFBP-3 and -6 levels in LS were markedly reduced upon $\mathrm{H}_{2} \mathrm{O}_{2}$ treatment in comparison to control cells. This differential pattern was correlated with increased apoptosis in LS cells following oxidative damage. It is reasonable to assume that enhanced apoptosis may constitute a protection mechanism that prevents survival of damaged cells.

\section{Interactions between Tumor Suppressor p53- and IGF1-Signaling Pathways}

The biological interaction between the IGF1 and p53 pathways has been a topic of major interest in oncology [93]. Given the key role of p53 in the DNA damage response, analysis of the interplay between p53-IGF1 is expected to have major biological ramifications. p53 is activated in response to a wide spectrum of cellular stress signals, including DNA damage and telomere shortening, hypoxia, inflammation, and, finally, activation of oncogenes by mutations [94]. Accumulation of mutations constitutes an early event in malignant transformation and may lead to the establishment of a tumor [95]. p53-mediated cell cycle arrest enables damaged DNA to be repaired before the replicative phase of the cell cycle.

We have generated evidence that the mechanism of action of wild-type p53 involves transcriptional suppression of the IGF1R gene [96-98]. Mutation of p53 in tumor cells disrupts its inhibitory activity, generating oncogenic molecules capable of transactivating the IGF1R gene [16]. Lack of IGF1R inhibition by mutant p53 molecules may help expand cancer cell populations that are otherwise destined to die. The p53 homologues p63 and p73 exhibit some of the biological properties of p53, including the ability to recognize and bind p53 target sequences, transactivate p53-responsive genes, and induce apoptosis [99] (Figure 6).

Studies have suggested a convergence of the p53 and IGF1 signaling paths that results in a feed-back regulatory loop. IGF1 induces p53 degradation in an Mdm2- (an ubiquitin ligase) dependent manner, while Mdm2 physically associates with IGF1R and causes its ubiquitination and degradation [100-102]. Very low IGF1 concentrations in LS may result in high cellular p53 levels, a key element of the genome protection machinery. 


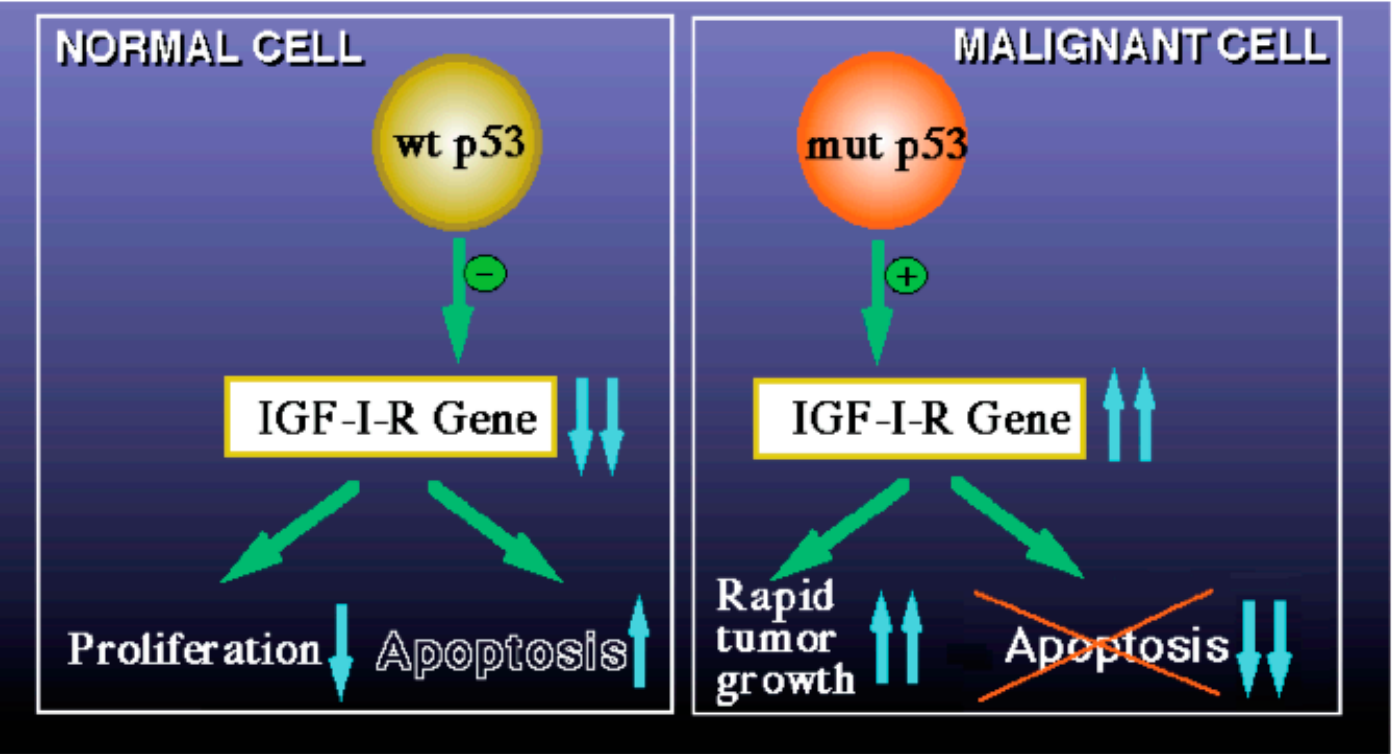

Figure 6. Schematic diagram of the regulation of IGF1R gene expression by wild-type and mutant p53. The mechanism of action of wild-type p53 involves transcriptional suppression of the IGF1R gene (left panel). Reduced IGF1R levels favor a post-mitotic, terminally-differentiated phenotype. Mutation of the $p 53$ gene in tumor cells disrupts its inhibitory activity, generating oncogenic molecules capable of transactivating the IGF1R gene (right panel). The abundance and activity of p53 itself is regulated by IGF1, which induces p53 degradation in an Mdm2-dependent fashion.

\section{Conclusions}

The finding that homozygous LS patients do not develop cancer (at least up to the age of 85) is of exceptional clinical and scientific value. The epidemiological data presented here confirm the hypothesis that the GH-IGF1 axis has a fundamental role in shaping a cell's decision on whether to adopt an apoptotic or, alternatively, oncogenic path. Our comprehensive analyses demonstrate that life-long lack of exposure to IGF1 in LS activates apoptotic, autophagic, and cancer-protecting pathways at the organism level. Concomitantly, reduced IGF1 signaling might have a major impact on nutrient sensing and response to oxidative stress.

By 'mining' genomic data from LS patients, a rare condition associated with cancer protection, we were able to generate clinically-relevant novel information and to translate this evidence into new avenues of research in oncology. We believe that this 'experiment of nature' will prove useful in other areas of investigation, including metabolism, nutrition, aging, and longevity. Future mechanistic analyses of newly identified IGF1 target genes will help unravel the connection between the IGF1 pathway, cell metabolism, and cancer protection.

Funding: Work in the laboratory of H.W. was supported by grants from the Israel Science Foundation, US-Israel Binational Science Foundation, Israel Cancer Association, European Foundation for the Study of Diabetes, Dotan Research Center in Hemato-Oncology, and the Recanati Foundation (Tel Aviv University).

Acknowledgments: H.W. is the incumbent of the Lady Davis Chair in Biochemistry.

Conflicts of Interest: The authors declare no conflict of interest.

\section{References}

1. LeRoith, D.; Yakar, S. Mechanisms of disease: Metabolic effects of growth hormone and insulin-like growth factor-1. Nat. Clin. Pract. Endocrinol. Metab. 2007, 3, 302-310. [CrossRef]

2. Yakar, S.; Adamo, M.L. Insulin-like growth factor 1 physiology: Lessons from mouse models. Endocrinol. Metab. Clin. N. Am. 2012, 41, 231-247. [CrossRef] 
3. Salmon, W.D.; Daughaday, W.H. A hormonally controlled serum factor which stimulates sulfate incorporation by cartilage in vitro. J. Lab. Clin. Med. 1957, 49, 825-836. [PubMed]

4. Bentov, I.; Werner, H. Insulin-like growth factors and breast cancer. Curr. Med. Lit.-Breast Cancer 2009, 21, 113-120.

5. Longo, V.; Finch, C. Evolutionary medicine: From dwarf model systems to healthy centenarians? Science 2003, 299, 1342-1346. [CrossRef] [PubMed]

6. Bentov, I.; Werner, H. IGF, IGF receptor and overgrowth syndromes. Pediatr. Endocrinol. Rev. 2004, 1, 352-360.

7. Baserga, R.; Peruzzi, F.; Reiss, K. The IGF-1 receptor in cancer biology. Int. J. Cancer 2003, 107, 873-877. [CrossRef]

8. Lu, K.; Campisi, J. Ras proteins are essential and selective for the action of insulin-like growth factor 1 late in the G1 phase of the cell cycle in BALB/c murine fibroblasts. Proc. Natl. Acad. Sci. USA 1992, 89, 3889-3893. [CrossRef]

9. Moschos, S.J.; Mantzoros, C.S. The role of the IGF system in cancer: From basic to clinical studies and clinical applications. Oncology 2002, 63, 317-332. [CrossRef]

10. Werner, H. Tumor suppressors govern insulin-like growth factor signaling pathways: Implications in metabolism and cancer. Oncogene 2012, 31, 2703-2714. [CrossRef] [PubMed]

11. Baserga, R. The contradictions of the insulin-like growth factor 1 receptor. Oncogene 2000, 19, 5574-5581. [CrossRef]

12. Werner, H.; Bruchim, I. The insulin-like growth factor-I receptor as an oncogene. Arch. Physiol. Biochem. 2009, 115, 58-71. [CrossRef]

13. Resnicoff, M.; Burgaud, J.-L.; Rotman, H.L.; Abraham, D.; Baserga, R. Correlation between apoptosis, tumorigenesis, and levels of insulin-like growth factor I receptors. Cancer Res. 1995, 55, 3739-3741.

14. Chitnis, M.M.; Yuen, J.S.P.; Protheroe, A.S.; Pollak, M.; Macaulay, V.M. The type I insulin-like growth factor-I receptor pathway. Clin. Cancer Res. 2008, 14, 6364-6370. [CrossRef]

15. Werner, H.; Shalita-Chesner, M.; Abramovitch, S.; Idelman, G.; Shaharabani-Gargir, L.; Glaser, T. Regulation of the insulin-like growth factor-I receptor gene by oncogenes and antioncogenes: Implications in human cancer. Mol. Gen. Metab. 2000, 71, 315-320. [CrossRef] [PubMed]

16. Sarfstein, R.; Maor, S.; Reizner, N.; Abramovitch, S.; Werner, H. Transcriptional regulation of the insulin-like growth factor-1 receptor in breast cancer. Mol. Cell. Endocrinol. 2006, 252, 241-246. [CrossRef]

17. Holly, J.M.P.; Biernacka, K.; Perks, C.M. The neglected insulin: IGF-II, a metabolic regulator with implications for diabetes, obesity, and cancer. Cells 2019, 8, 1207. [CrossRef]

18. Kessler, S.M.; Haybaeck, J.; Kiemer, A.K. Insulin-like growth factor 2-The oncogene and its accomplices. Curr. Pharm. Des. 2016, 22, 5948-5961. [CrossRef]

19. Bach, L. Insulin-like growth factor binding proteins-An update. Pediatr. Endocrinol. Rev. 2015, 13, 521-530.

20. Baxter, R.C. IGF binding proteins in cancer: Mechanistic and clinical insights. Nat. Rev. Cancer 2014, 14, 329-341. [CrossRef] [PubMed]

21. Klammt, J.; Pfaffle, R.; Werner, H.; Kiess, W. IGF signaling defects as causes of growth failure and IUGR. Trends Endocrinol. Metab. 2008, 19, 197-205. [CrossRef]

22. Rosenfeld, R.G. The molecular basis of idiophatic short stature. Growth Horm. IGF Res. 2005, 15 (Suppl. A), S3-S5. [CrossRef]

23. Solomon-Zemler, R.; Basel-Vanagaite, L.; Steier, D.; Yakar, S.; Mel, E.; Phillip, M.; Bazak, L.; Bercovich, D.; Werner, H.; de Vries, L. A novel heterozygous IGF-1 receptor mutation associated with hypoglycemia. Endocr. Connect. 2017, 6, 395-403. [CrossRef]

24. Cohen, P.; Rogol, A.D.; Deal, C.L.; Saenger, P.; Reiter, E.O.; Ross, J.L.; Chernausek, S.D.; Savage, M.O.; Wit, J.M. 2007 ISS Consensus Workshop participants. Consensus statement on the diagnosis and treatment of children with idiopathis short stature: A summary of the Growth Hormone Research Society, The Lawson Wilkins Pediatric Endocrine Society and the European Society for Pediatric Endocrinology Workshop. J. Clin. Endocrinol. Metab. 2008, 93, 4210-4217.

25. Woods, K.A.; Camacho-Hubner, C.; Savage, M.O.; Clark, A.J.L. Intrauterine growth retardation and postnatal growth failure associated with deletion of the insulin-like growth factor I gene. N. Engl. J. Med. 1996, 335, 1363-1367. [CrossRef]

26. Domene, H.; Bengolea, S.V.; Martinez, A.S.; Ropelato, M.G.; Pennisi, P.; Scaglia, P.; Heinrich, J.; Jasper, H. Deficiency of the circulating IGF system associated with inactivation of the acid-labile subunit gene. N. Engl. J. Med. 2004, 350, 570-577. [CrossRef] 
27. Domené, S.; Domené, H.M. Genetic mutations in the GH/IGF axis. Pediatr. Endocrinol. Rev. 2018, 16, $39-62$.

28. Kofoed, E.M.; Hwa, V.; Little, B.; Woods, K.A.; Buckway, C.K.; Tsubaki, J.; Pratt, K.L.; Bezrodni, L.; Jasper, H.; Tepper, A.; et al. Growth hormone insensitivity associated with a STAT5b mutation. N. Engl. J. Med. 2003, 349, 1139-1147. [CrossRef] [PubMed]

29. Argente, J.; Chowen, J.A.; Perez-Jurada, L.A.; Frystyk, J.; Oxvig, C. One level up: Abnormal proteolytic regulation of IGF activity plays a role in human pathophysiology. EMBO Mol. Med. 2017, 9, 1338-1345. [CrossRef]

30. Dauber, A.; Muñoz-Calvo, M.T.; Barrios, V.; Domené, H.M.; Kloverpris, S.; Serra-Juhé, C.; Desikan, V.; Pozo, J.; Muzumdar, R.; Martos-Moreno, G.Á.; et al. Mutations in pregnancy-associated plasma protein A2 cause short stature due to low IGF-I availability. EMBO Mol. Med. 2016, 8, 363-374. [CrossRef] [PubMed]

31. Baker, J.; Liu, J.-P.; Robertson, E.J.; Efstratiadis, A. Role of insulin-like growth factors in embryonic and postnatal growth. Cell 1993, 75, 73-82. [CrossRef]

32. Liu, J.-P.; Baker, J.; Perkins, A.S.; Robertson, E.J.; Estratiadis, A. Mice carrying null mutations of the genes encoding insulin-like growth factor I (Igf-1) and type 1 IGF receptor (Igf1r). Cell 1993, 75, 59-72. [CrossRef]

33. Lupu, F.; Terwilliger, J.D.; Lee, K.; Segre, G.V.; Efstratiadis, A. Roles of growth hormone and insulin-like growth factor 1 in mouse postnatal growth. Dev. Biol. 2001, 229, 141-162. [CrossRef]

34. Yakar, S.; Liu, J.L.; Stannard, B.; Butler, A.; Accili, D.; Sauer, B.; LeRoith, D. Normal growth and development in the absence of hepatic insulin-like growth factor I. Proc. Natl. Acad. Sci. USA 1999, 96, 7324-7329. [CrossRef]

35. List, E.O.; Berryman, D.E.; Funk, K.; Jara, A.; Kelder, B.; Wang, F.; Stout, M.B.; Zhi, X.; Sun, L.; White, T.A.; et al. Liver-specific GH receptor gene-disrupted (LiGHRKO) mice have decreased endocrine IGF-I, increased local IGF-I, and altered body size, body composition, and adipokine profiles. Endocrinology 2014, 155, 1793-1805. [CrossRef] [PubMed]

36. Mancarella, C.; Scotlandi, K. IGF system in sarcomas: A crucial pathway with many unknowns to exploit for therapy. J. Mol. Endocrinol. 2018, 61, T45-T60. [CrossRef]

37. Hankinson, S.E.; Willett, W.C.; Colditz, G.A.; Hunter, D.J.; Michaud, D.S.; Deroo, B.; Rosner, B.; Speizer, F.E.; Pollak, M. Circulating concentrations of insulin-like growth factor-I and risk of breast cancer. Lancet 1998, 351, 1393-1396. [CrossRef]

38. Chan, J.M.; Stampfer, M.J.; Giovannucci, E.; Gann, P.H.; Ma, J.; Wilkinson, P.; Hennekens, C.H.; Pollak, M. Plasma insulin-like growth factor-I and prostate cancer risk: A prospective study. Science 1998, 279, 563-566. [CrossRef]

39. Ma, J.; Pollack, M.N.; Giovannucci, E.; Chan, J.M.; Tao, Y.; Hennekens, C.H.; Stampfer, M.J. Prospective study of colorectal cancer risk in men and plasma levels of insulin-like growth factor (IGF)-I and IGF-binding protein-3. J. Natl. Cancer Inst. 1999, 91, 620-625. [CrossRef]

40. Holly, J.M.P.; Gunnell, D.J.; Davey Smith, G. Growth hormone, IGF-I and cancer. Less intervention to avoid cancer? More intervention to prevent cancer? J. Endocrinol. 1999, 162, 321-330. [CrossRef]

41. Cianfarani, S.; Tedeschi, B.; Germani, D.; Prete, S.P.; Rossi, P.; Vernole, P.; Caporossi, D.; Boscherini, B. In vitro effects of growth hormone (GH) and insulin-like growth factor I and II (IGF-I and -II) on chromosome fragility and p53 protein expression in human lymphocytes. Eur. J. Clin. Investig. 1998, 28, 41-47. [CrossRef]

42. Cohen, S.M.; Ellwein, L.B. Cell proliferation in carcinogenesis. Science 1990, 249, $1007-1011$. [CrossRef] [PubMed]

43. Laron, Z. Lessons from 50 years of study of Laron syndrome. Endocr. Pract. 2015, 21, 1395-1402. [CrossRef]

44. Laron, Z. Extensive personal experience. Laron syndrome (primary growth hormone resistance or insensitivity): The personal experience 1958-2003. J. Clin. Endocrinol. Metab. 2004, 89, 1031-1044. [CrossRef]

45. Laron, Z.; Kopchik, J.J. Laron Syndrome-From Man to Mouse; Springer: Berlin/Heidelberg, Germany, 2011; pp. 1-525.

46. Werner, H.; Lapkina-Gendler, L.; Laron, Z. Fifty years on: New lessons from Laron syndrome. Isr. Med. Assoc. J. 2017, 19, 6-7.

47. Laron, Z.; Pertzelan, A.; Mannheimer, S. Genetic pituitary dwarfism with high serum concentration of growth hormone-a new inborn error of metabolism? Isr. J. Med. Sci. 1966, 2, 152-155.

48. Rosenfeld, R.G.; Rosenbloom, A.L.; Guevara-Aguirre, J. Growth hormone insensitivity due to primary GH receptor deficiency. Endocr. Rev. 1994, 15, 369-390. [CrossRef]

49. Glick, S.M.; Roth, J.; Yallow, R.S.; Berson, S.A. Immunoassay of human growth hormone in plasma. Nature 1963, 199, 784-788. [CrossRef] 
50. Eshet, R.; Laron, Z.; Brown, M.; Arnon, R. Immunoreactive properties of the plasma hGH from patients with the syndrome of familial dwarfism with high plasma IR-hGH. J. Clin. Endocrinol. Metab. 1973, 37, 819-821. [CrossRef]

51. Eshet, R.; Laron, Z.; Pertzelan, A.; Arnon, R.; Dintzman, M. Defects of human growth hormone receptors in the liver of two patients with Laron-type dwarfism. Isr. J. Med. Sci. 1984, 20, 8-11.

52. Godowski, P.J.; Leung, D.W.; Meacham, L.R.; Galgani, J.P.; Hellmiss, R.; Keret, R.; Rotwein, P.S.; Parks, J.S.; Laron, Z.; Wood, W.I. Characterization of the human growth hormone receptor gene and demonstration of a partial gene deletion in two patients with Laron-type dwarfism. Proc. Natl. Acad. Sci. USA 1989, 86, 8083-8087. [CrossRef]

53. Amselem, S.; Duquesnoy, P.; Attree, O.; Novelli, G.; Bousnina, S.; Postel-Vinay, M.C.; Goossens, M. Laron dwarfism and mutations of the growth hormone-receptor gene. N. Engl. J. Med. 1989, 321, 989-995. [CrossRef]

54. Shevah, O.; Laron, Z. Genetic analysis of the pedigrees and molecular defects of the GH-receptor gene in the Israeli cohort of patients with Laron syndrome. Pediatr. Endocrinol. Rev. 2006, 3 (Suppl. 3), 489-497.

55. Rosenbloom, A.L.; Guevara-Aguirre, J. Lessons from the genetics of Laron syndrome. Trends Endocrinol. Metab. 1998, 9, 276-283. [CrossRef]

56. Goncalves, F.T.; Fridman, C.; Pinto, E.M.; Guevara-Aguirre, J.; Shevah, O.; Rosenbloom, A.L.; Hwa, V.; Cassorla, F.; Rosenfeld, R.G.; Lins, T.S.S.; et al. The E180 splice mutation in the GHR gene causing Laron syndrome: Witness of a Sephardic Jewish exodus from the Iberian Peninsula to the New World? Am. J. Med. Genet. 2014, 164, 1204-1208. [CrossRef]

57. Zhou, Y.; Xu, B.C.; Maheshwari, H.G.; He, L.; Reed, M.; Lozykowski, M.; Okada, S.; Cataldo, L.; Coschigamo, K.; Wagner, T.E.; et al. A mammalian model for Laron syndrome produced by targeted disruption of the mouse growth hormone receptor/binding protein gene (the Laron mouse). Proc. Natl. Acad. Sci. USA 1997, 94, 13215-13220. [CrossRef]

58. Guevara-Aguirre, J.; Rosenbloom, A.L.; Vasconez, O.; Martinez, V.; Gargosky, S.E.; Allen, L.; Rosenfeld, R.G. Two year treatment of GH receptor deficiency with recombinant IGF-I in 22 children: Comparison of two dosage levels and to GH treated GH deficiency. J. Clin. Endocrinol. Metab. 1997, 82, 629-633.

59. Backeljauw, P.F.; Underwood, L.E.; GHIS Collaborative Group. Therapy for 6.5-7.5 years with recombinant IGF-I in children with growth hormone insensitivity syndrome: A clinical research center study. J. Clin. Endocrinol. Metab. 2001, 86, 1504-1510.

60. Laron, Z.; Klinger, B. Comparison of the growth promoting effects of IGF-I and growth hormone in the early years of life. Acta Paediatr. 2000, 88, 38-41. [CrossRef]

61. Werner, H.; Lapkina-Gendler, L.; Nagaraj, K.; Sarfstein, R.; Laron, Z. Genome-wide profiling of congenital IGF1 deficient patients: Translational implications in cancer prevention and metabolism. Transl. Med. Rep. 2017, 1, 6657. [CrossRef]

62. Shevah, O.; Laron, Z. Patients with congenital deficiency of IGF-I seem protected from the development of malignancies: A preliminary report. Growth Horm. IGF Res. 2007, 17, 54-57. [CrossRef] [PubMed]

63. Steuerman, R.; Shevah, O.; Laron, Z. Congenital IGF1 deficiency tends to confer protection against post-natal development of malignancies. Eur. J. Endocrinol. 2011, 164, 485-489. [CrossRef]

64. Guevara-Aguirre, J.; Balasubramanian, P.; Guevara-Aguirre, M.; Wei, M.; Madia, F.; Cheng, C.W.; Hwang, D.; Martin-Montalvo, A.; Saavedra, J.; Ingles, S.; et al. Growth hormone receptor deficiency is associated with a major reduction in pro-aging signaling, cancer, and diabetes in humans. Sci. Transl. Med. 2011, 3, 70ra13. [CrossRef]

65. Wang, Z.; Prins, G.S.; Coschigano, K.T.; Kopchick, J.J.; Green, J.E.; Ray, V.H.; Hedayat, S.; Christov, K.T.; Unterman, T.G.; Swanson, S.M. Disruption of growth hormone signaling retards early stages of prostate carcinogenesis in the C3(1)/T antigen mouse. Endocrinology 2005, 146, 5188-5196. [CrossRef]

66. Moore, T.; Carbajal, S.; Beltran, L.; Perkins, S.N.; Yakar, S.; LeRoith, D.; Hursting, S.D.; Digiovanni, J. Reduced susceptibility to two-stage skin carcinogenesis in mice with low circulating insulin-like growth factor-I levels. Cancer Res. 2008, 68, 3680-3688. [CrossRef]

67. Lapkina-Gendler, L.; Rotem, I.; Pasmanik-Chor, M.; Gurwitz, D.; Sarfstein, R.; Laron, Z.; Werner, H. Identification of signaling pathways associated with cancer protection in Laron syndrome. Endocr. Relat. Cancer 2016, 23, 399-410. [CrossRef]

68. Morag, A.; Kirchheiner, J.; Rehavi, M.; Gurwitz, D. Human lymphoblastoid cell line panels: Novel tools for assessing shared drug pathways. Pharmacogenomics 2010, 11, 327-340. [CrossRef] 
69. Vidal, A.C.; Tucker, C.; Schildkraut, J.M.; Richardson, R.M.; McPhail, M.; Freedland, S.J.; Hoyo, C.; Grant, D.J. Novel associations of UDP-glucuronosyltransferase $2 \mathrm{~B}$ gene variants with prostate cancer risk in a multiethnic study. BMC Cancer 2013, 13, 556. [CrossRef]

70. Zhang, H.; Basit, A.; Busch, D.; Yabut, K.; Bhatt, D.K.; Drozdzik, M.; Ostrowski, M.; Li, A.; Collins, C.; Oswald, S.; et al. Quantitative characterization of UDP-glucuronosyltransferase 2B17 in human liver and intestine and its role in testosterone first-pass metabolism. Biochem. Pharmacol. 2018, 156, 32-42. [CrossRef]

71. Achlaug, L.; Sarfstein, R.; Nagaraj, K.; Lapkina-Gendler, L.; Bruchim, I.; Dixit, M.; Laron, Z.; Yakar, S.; Werner, H. Identification of ZYG11A as a candidate IGF1-dependent proto-oncogene in endometrial cancer. Oncotarget 2019, 10, 4437-4448. [CrossRef] [PubMed]

72. Sarfstein, R.; Lapkina-Gendler, L.; Nagaraj, K.; Laron, Z.; Werner, H. Identification of nephronectin as a new target for IGF1 action. Eur. J. Cancer 2020, 141, 115-127. [CrossRef]

73. Rosenfeldt, M.T.; Ryan, K.M. The multiple roles of autophagy in cancer. Carcinogenesis 2011, 32, $955-963$. [CrossRef] [PubMed]

74. Mizushima, N.; Yoshimori, T. How to interpret LC3 immunoblotting. Autophagy 2007, 3, 542-545. [CrossRef]

75. Moscat, J.; Diaz-Meco, M.T. p62 at the crossroads of autophagy, apoptosis, and cancer. Cell 2009, 137, 1001-1004. [CrossRef]

76. Patwari, P.; Higgins, L.J.; Chutkow, W.A.; Yoshioka, J.; Lee, R.T. The interaction of thioredoxin with Txnip: Evidence for formation of a mixed disulfide by disulfide exchange. J. Biol. Chem. 2006, 281, 21884-21891. [CrossRef]

77. Chen, K.S.; DeLuca, H.F. Isolation and characterization of a novel cDNA from HL-60 cells treated with 1,25-dihydroxyvitamin D-3. Biochim. Biophys. Acta Gene Struct. Expr. 1994, 1219, 26-32. [CrossRef]

78. Takeuchi, J.; Hirota, K.; Itoh, T.; Shinkura, R.; Kitada, K.; Yodoi, J.; Namba, T.; Fukuda, K. Thioredoxin inhibits tumor necrosis factor- or interleukin-1-induced NF-kappaB activation at a level upstream of NF-kappaB-inducing kinase. Antioxid. Redox Signal. 2000, 2, 83-92. [CrossRef]

79. Shah, A.; Xia, L.; Goldberg, H.; Lee, K.W.; Quaggin, S.E.; Fantus, I.G. Thioredoxin-interacting protein mediates high glucose-induced reactive oxygen species generation by mitochondria and the NADPH oxidase, Nox4, in mesangial cells. J. Biol. Chem. 2013, 288, 6835-6848. [CrossRef]

80. Junn, E.; Han, S.H.; Im, J.Y.; Yang, Y.; Cho, E.W.; Um, H.D.; Kim, D.K.; Lee, K.W.; Han, P.L.; Rhee, S.G.; et al. Vitamin D3 up-regulated protein 1 mediates oxidative stress via suppressing the thioredoxin function. J. Immunol. 2000, 164, 6287-6295. [CrossRef]

81. Nagaraj, K.; Lapkina-Gendler, L.; Sarfstein, R.; Gurwitz, D.; Pasmanik-Chor, M.; Laron, Z.; Yakar, S.; Werner, H. Identification of thioredoxin-interacting protein (TXNIP) as a downstream target for IGF1 action. Proc. Natl. Acad. Sci. USA 2018, 115, 1045-1050. [CrossRef]

82. Spindel, O.N.; World, C.; Berk, B.C. Thioredoxin interacting protein: Redox dependent and independent regulatory mechanisms. Antioxid. Redox Signal. 2012, 16, 587-596. [CrossRef]

83. Thielen, L.A.; Chen, J.; Jing, G.; Moukha-Chafiq, O.; Xu, G.; Jo, S.-H.; Grayson, T.B.; Lu, B.; Li, P.; Augelli-Szafran, C.E.; et al. Identification of an anti-diabetic, orally available small molecule that regulates TXNIP expression and glucagon action. Cell Metab. 2020, 32, 353-365. [CrossRef]

84. Somri, L.; Sarfstein, R.; Lapkina-Gendler, L.; Nagaraj, K.; Laron, Z.; Bach, L.A.; Werner, H. Differential expression of IGFBPs in Laron syndrome-derived lymphoblastoid cell lines: Potential correlation with reduced cancer incidence. Growth Horm. IGF Res. 2018, 39, 6-12. [CrossRef]

85. Hettmer, S.; Dannecker, L.; Foell, J.; Elmlinger, M.; Dannecker, G. Effects of insulin-like growth factors and insulin-like growth factor binding protein-2 on the in vitro proliferation of peripheral blood mononuclear cells. Hum. Immunol. 2005, 66, 95-103. [CrossRef]

86. Yasuoka, H.; Yamaguchi, Y.; Feghali-Bostwick, C.A. The pro-fibrotic factor IGFBP-5 induces lung fibroblast and mononuclear cell migration. Am. J. Respir. Cell. Mol. Biol. 2009, 41, 179-188. [CrossRef]

87. Liso, A.; Castellani, S.; Massenzio, F.; Trotta, R.; Pucciarini, A.; Bigerna, B.; De Luca, P.; Zoppoli, P.; Castiglione, F.; Palumbo, M.C.; et al. Human monocyte-derived dendritic cells exposed to hyperthermia show a distinct gene expression profile and selective upregulation of IGFBP6. Oncotarget 2017, 8, 60826-60840. [CrossRef] [PubMed]

88. Liu, B.; Lee, K.; Anzo, M.; Zhang, B.; Zi, X.; Tao, Y.; Shiry, L.; Pollak, M.; Lin, S.; Cohen, P. Insulin-like growth factor-binding protein-3 inhibition of prostate cancer growth involves suppression of angiogenesis. Oncogene 2007, 26, 1811-1819. [CrossRef] [PubMed] 
89. Fielder, P.J.; Guevara-Aguirre, J.; Rosenbloom, A.L.; Carlsson, L.; Hintz, R.L.; Rosenfeld, R.G. Expression of serum insulin-like growth factors, insulin-like growth factor-binding proteins, and the growth hormone-binding protein in heterozygote relatives of Ecuadorian growth hormone receptor deficient patients. J. Clin. Endocrinol. Metab. 1992, 74, 743-750. [CrossRef]

90. Cotterill, A.M.; Holly, J.M.P.; Taylor, A.M.; Davies, S.C.; Coulson, V.J.; Preece, M.A.; Wass, J.A.H.; Savage, M.O. The insulin-like growth factor (IGF)-binding proteins and IGF bioactivity in Laron-type dwarfism. J. Clin. Endocrinol. Metab. 1992, 74, 56-63.

91. Kanety, H.; Karasik, A.; Klinger, B.; Silbergeld, A.; Laron, Z. Long-term treatment of Laron type dwarfs with insulin-like growth factor-1 increases serum IGF-binding protein-3 in the absence of growth hormone activity. Acta Endocrinol. 1993, 128, 144-149. [CrossRef] [PubMed]

92. Laron, Z. IGF-I binding proteins in Laron syndrome. In Laron Syndrome: From Man to Mouse; Laron, Z., Kopchik, J., Eds.; Springer: Berlin/Heidelberg, Germany, 2011.

93. Werner, H.; Sarfstein, R.; LeRoith, D.; Bruchim, I. Insulin-like growth factor 1 signaling axis meets p53 genome protection pathways. Front. Oncol. 2016, 6, 159. [CrossRef]

94. Bieging, K.T.; Mello, S.S.; Attardi, L.D. Unravelling mechanisms of p53-mediated tumour suppression. Nat. Rev. Cancer 2014, 14, 359-370. [CrossRef]

95. Kruiswijk, F.; Labuschagne, C.F.; Vousden, K.H. p53 in survival, death and metabolic health: A lifeguard with a licence to kill. Nat. Rev. Mol. Cell Biol. 2015, 16, 393-405. [CrossRef]

96. Abramovitch, S.; Werner, H. Functional and physical interactions between BRCA1 and p53 in transcriptional regulation of the IGF-IR gene. Horm. Metab. Res. 2003, 35, 758-762. [PubMed]

97. Attias-Geva, Z.; Bentov, I.; Kidron, D.; Amichay, K.; Sarfstein, R.; Fishman, A.; Bruchim, I.; Werner, H. p53 regulates insulin-like growth factor-I receptor gene expression in uterine serous carcinoma and predicts responsiveness to an insulin-like growth factor-I receptor-directed targeted therapy. Eur. J. Cancer 2012, 48, 1570-1580. [CrossRef]

98. Werner, H.; Karnieli, E.; Rauscher, F.J., III; LeRoith, D. Wild type and mutant p53 differentially regulate transcription of the insulin-like growth factor I receptor gene. Proc. Natl. Acad. Sci. USA 1996, 93, 8318-8323. [CrossRef]

99. Nahor, I.; Abramovitch, S.; Engeland, K.; Werner, H. The p53-family members p63 and p73 inhibit insulin-like growth factor-I receptor gene expression in colon cancer cells. Growth Horm. IGF Res. 2005, 15, 388-396. [CrossRef]

100. Heron-Milhavet, L.; LeRoith, D. Insulin-like growth factor I induces MDM2-dependent degradation of p53 via the p38 MAPK pathway in response to DNA damage. J. Biol. Chem. 2002, 277, 15600-15606. [CrossRef] [PubMed]

101. Girnita, L.; Girnita, A.; Larsson, O. Mdm2-dependent ubiquitination and degradation of the insulin-like growth factor-I receptor. Proc. Natl. Acad. Sci. USA 2003, 100, 8247-8252. [CrossRef] [PubMed]

102. Girnita, L.; Girnita, A.; Brodin, B.; Xie, Y.; Nilsson, G.; Dricu, A.; Lundeberg, J.; Wejde, J.; Bartolazzi, A.; Wiman, K.G.; et al. Increased expression of insulin-like growth factor I receptor in malignant cells expressing aberrant p53: Functional impact. Cancer Res. 2000, 60, 5278-5283.

Publisher's Note: MDPI stays neutral with regard to jurisdictional claims in published maps and institutional affiliations.

(C) 2020 by the authors. Licensee MDPI, Basel, Switzerland. This article is an open access article distributed under the terms and conditions of the Creative Commons Attribution (CC BY) license (http://creativecommons.org/licenses/by/4.0/). 